\title{
INTERNATIONAL FINANCE AND TAX
}

\section{Emerging market bank rescues in an era of finance-led neoliberalism: A comparison of Mexico and Turkey}

\author{
Thomas Marois \\ Department of Development Studies, SOAS, University of London, UK
}

\begin{abstract}
The international community and many financial experts have singled out the positive elements of how strong institutional reforms following Mexico's 1995 and Turkey's 2001 banking crisis have shielded their banking sectors today from the wider economic impact of the world financial crisis. By contrast, this article argues from a historical materialist analytical approach that the 1995 and 2001 bank rescues and reforms preserved, renewed, and intensified the structurally unequal social relations of power and class characteristic of finance-led neoliberal capitalism in forms institutionally specific to Mexican and Turkish society. The post-crisis reforms reinforced the dominance of banking and finance capital in Mexico and Turkey at the expense of popular classes and society in general, and it is this dynamic of power that explains the resilience of banks today.
\end{abstract}

\section{KEYWORDS}

Mexico; Turkey; banking; rescue; neoliberalism; finance.

\section{INTRODUCTION}

As late as September 2008, financial experts continued to hope that an economic downturn in emerging markets like Mexico and Turkey might yet be avoided despite the sub-prime volatility emanating from the US. The situation worsened in October, however, following the collapse of the banking giant Lehman Brothers at which point, according to International Monetary Fund (IMF) Chief Dominique Strauss-Kahn, the world economy was very close to 'total collapse'. ${ }^{1}$ Any hope that the havoc being experienced in the US might not now spill over into a world financial crisis 
dissipated. The US, European, and the Chinese financial rescues were of the most immediate concern. Once approved in early 2009, the Group of Twenty (G-20) leaders and international financial institutions (IFIs) turned their attention to the plight of emerging markets. In a February 2009 joint statement, the IMF, Organisation for Economic Co-operation and Development (OECD), and World Bank conceded that these countries would be hardest hit in the coming year. ${ }^{2}$

The consequences of the sub-prime crisis for emerging markets like Mexico and Turkey have been severe (IMF 2009b). International flows of capital have slowed dramatically and world trade and industrial output have plummeted causing unemployment to skyrocket and recession to sink in. Yet while major banks in the US and Europe have collapsed or required unequaled government interventions, the banks in Mexico and Turkey - places not normally associated with financial stability - have proven remarkably resilient. In fact, the IMF suggests the crisis will have only a modest impact on the Mexican banks and World Bank President Robert Zoellick believes the Turkish banking sector to be shock-proof. ${ }^{3}$ How is this possible? To be sure, Mexico and Turkey's less advanced security and capital markets have a lot to do with it. However, many financial commentators also point to Mexico's 1995 and Turkey's 2001 bank crises and, more directly, to the reforms they believe have since insulated the bank sectors. The banks have fared well, and post-crisis reforms are the obvious explanation. Or so it seems. Underneath such descriptive assessments, there remain more profound questions of who benefits and why from the bank rescues.

The following seeks to address these relatively unexplored questions from a historical materialist analytical framework sensitive to the social relations of power and class. Rather than simply insulating the sectors, I argue that the 1995 Mexican and 2001 Turkish bank rescues internalized deeper social aspects of universalization and differentiation. Universalization insofar as the unequal class structures of power specific to the current phase of finance-led neoliberal capitalism are preserved, renewed, and intensified in the rescue process. Differentiation insofar as universalization assumes institutional forms specific to Mexican and Turkish society. According to this interpretation, the stability of their banks today has depended on states reinforcing the power of finance at the expense of popular classes.

Following a review of the literature, I develop this argument based on how, at the level of state, the Mexican and Turkish bank rescues have tended to socialize bad debts and risks, rationalize the banking sector, and internationalize the state financial apparatus according to a marketoriented rationale. I then explore how, at the level of the competitive world market, the bank rescues have accelerated pre-existing structural tendencies towards the centralization and concentration of bank capital as well 
(Demirgüç-Kunt and Servén 2009: 45-6). In the case of Mexico, Stephen Haber (2005: 2328) criticizes how the presidency politicizes economic processes, which distorted the Mexican banking sector and led to the 1995 banking crisis. He believes that Mexican authorities have since moved in the right direction, but have yet to successfully release market discipline.

There are debates within and across the liberal and institutional political economy camps, yet there is a shared concern for crafting the right mix of policy and institutional dynamics needed to enhance market-oriented and capitalist developmental processes (Allegret et al., 2003). How the social relations of power and class shape institutional changes are not their primary concern.

The historical materialist or Marxian approach adopted here responds, as Gerard Greenfield (2004) argues, to the need to move beyond institutions and policy, without jettisoning them, to examine underlying power relations and structures. This means looking at neoliberalism as a new social configuration and form of rule wherein the outcomes of crises have technical and institutional dimensions, but ones that are determined by domestic and international political forces (Duménil and Lévy, 2004: 674). At the same time, states and societies are compelled to adjust to new competitive financial imperatives associated with neoliberal capitalism (Albo, 2005). This suggests that neoliberal social rule today need also be understood as finance-led. The choices available to individuals, collectives, and states are more forcefully subjected to the discipline of money, creditworthiness, and speculative pressures in the world market than in earlier phases of capitalism (Bello, 2006). This is an expression of the reasserted power of finance since the 1980s, wherein 'finance' denotes the upper fraction of capitalist owners and their financial institutions (Duménil and Lévy, 2004: 660).

Finance-led neoliberal social rule does not mean structural determinacy. Rather, through interrelated and historically specific material, institutional, spatial, and discursive dynamics finance-led neoliberalism influences, shapes, and imparts a certain social logic upon individual and collective agencies. Cast in this light, Mexican and Turkish societies are not understood as agentless victims of structural adjustment. As Hamza Alavi (1982) reminds us, individual and collective agents in the periphery must be seen in the context of class divided societies and contending domestic social forces. The strength of this historical materialist account in this way rests in its analytical capacity to contextualize human rationality and institutions specific to Mexico and Turkey within a wider universalizing structural logic and sets of power relations historically specific to capitalism. Neither individuals nor institutions nor structures are seen as determinant relations in themselves. The post-war circumstances leading up to Mexico and Turkey's transition to neoliberalism are explored next. 


\section{POST-WAR TRANSITION TO NEOLIBERALISM IN MEXICO AND TURKEY}

In the absence of the more developed capital markets seen in the US and UK, the unique capacity of commercial banks to pool and augment scarce money savings shaped the preeminence of banks in Mexico and Turkey's early financial systems. In the aftermath of the 1910-17 Mexican Revolution, the ruling elite prioritized the mobilization of capital for industrialization. Consequently, the state apparatus worked to re-establish the collapsed banking sector (Bennett and Sharpe, 1980: 172; Gómez-Galvarriato and Recio, 2003). The private domestic banks then contributed to financing capitalist development through official reserve requirements held in the Bank of Mexico (BdeM; Banco de México), whose funds were then channeled into priority sectors. Likewise after the collapse of the Ottoman state in 1923, the new Turkish state needed to mobilize domestic capital. At the 1923 Izmir Congress, nascent Turkish capitalists and state elites articulated a system of state and privately owned banks that coexisted alongside minor foreign banks. The reserve requirement mechanism and the Central Bank of Turkey (TCMB; Türkiye Cumhuriyet Merkez Bankasi) helped to fund development as in Mexico, but the Turkish state banks through their institutionalized developmental missions also became important agents of industrialization.

While contentious with export-oriented capitalists, this form of state regulated banking was well-within international and American norms of development (Helleiner, 2006). State regulation helped to ensure growth nationally and stable profits for the banks. Tight state-market relations institutionally crystallized between the bankers and the government. At the time, having the banks be predominantly Mexican or Turkish, rather than foreign-owned, went almost unquestioned. This helped Mexico and Turkey achieve significant levels of industrialization and integration into the world market compared to colonial times.

Be that as it may, the barriers presented by capitalist development meant that the two countries remained subordinate within the hierarchy of interstate relations. State-led development had also put growing pressure on domestic finances. By the late 1970s, Mexico and Turkey faced serious financial and balance of payments problems that could not be overcome easily (FitzGerald, 1985: 227; Yalman, 2002: 37-8). Domestic capital reacted by way of investment strikes, which triggered a series of foreign exchange and debt crises by the 1980s. In Mexico, the outgoing Institutional Revolutionary Party (PRI; Partido Revolucionario Institucional) President José López Portillo reacted by nationalizing the domestic private banks on 1 September 1982 (Tello, 1984). This, however, had the unanticipated consequence of enabling a more rapid shift to neoliberalism by the incoming Miguel de la Madrid PRI administration than may have been otherwise 
possible (Marois, 2008). In Turkey, the predominance of no single bank ownership group meant that the control over bank capital was more dispersed. This reduced the likelihood of a Mexico-like bankers' strike and pressure to nationalize the banks as imbalances built up in the late 1970s - if for no other reason than the Turkish state banks controlled about half the banking sectors' assets. Rather, mounting class conflict meant Turkish state elites, backed by the 1980 military coup, intervened on behalf of the general interests of Turkish capitalism with rapid and authoritarian liberalizations (Savran, 2002).

Mexican and Turkish governments and financial managers, in collaboration with domestic and foreign capital, have since pursued market-oriented strategies of development under the guidance of IFIs and pressure of competitive imperatives. Yet the transition to neoliberalism and its finance-led form has triggered a rise in financial volatility. Mexico suffered one of the first major emerging market banking crises in 1995 and Turkey the most recent in 2001.

\section{The 1995 Mexican and 2001 Turkish bank crises}

To explore the tendencies of banking rescues, it is necessary to first revisit the circumstances behind the Mexican and Turkish bank crises. ${ }^{5}$ In Mexico, the privatization of all 18 state banks at once - which occurred rapidly between June 1991 and July 1992 and earned \$12.27 billion - was a significant factor leading to the 1995 crisis. Contrary to the PRI democratization of bank capital discourse, bank privatization resulted in a highly concentrated bank ownership structure within Mexican financial holding groups (Vidal, 2002: 22-5). The rapid sell-off process had also put tremendous pressure on Mexican capitalists to buy one of the banks being sold off or miss out. It was clear that not owning a bank would leave one in a weak competitive position for access to finance capital within Mexico, stimulating the bidding process. Once the sales were completed, moreover, the new holding group owners had to find ways to quickly recuperate their costs at the same time as all the other new bank owners. Most raced to open new branches and reduce labor costs (discussed below) and others channeled bank credits into other areas of the group experiencing financial difficulties - often at the expense of the holding group bank's operations (SHCP, 1998: 48). Both intensified competitive pressures and contributed to the outbreak of crisis in $1995 .{ }^{6}$ Yet this competitive struggle among capitalists was consistent with Mexico's new liberal development strategy that intended to augment free market discipline. Only after the 1995 crisis did state regulators point to the lack of regulation as problematic (cf. Ortiz, Martínez, 1993; SHCP 1998). The 1994 North American Free Trade Agreement (NAFTA) was in truth negotiated according to the perceived developmental benefits of market discipline and capitalist self-interest. What is more, President 
Carlos Salinas negotiated NAFTA in relative isolation to ensure NAFTA tied the hands of future governments to this neoliberal vision and because liberalization was not welcomed by all members of society (Guillén Romo, 2005: 89). The violent political conditions leading up to and following the NAFTA 1 January 1994 launch testify to the contested status of NAFTA.

While bank privatization and NAFTA implementation specifically influenced the outbreak of crisis in 1995, the general conditions for crisis had been in the making for more than a decade. Initial liberalizations since the late 1970s, and especially capital account liberalization in 1989, had encouraged the expansion of domestic credit (Levy, 2003: 168). Bank privatization cranked up this expansion that was on the whole consumer based and sustained by the domestic banks borrowing short-term foreign credits (SHCP, 1998: 10-11). It is not surprising that the privatized banks took advantage of all the tools provided them by liberalization, including high levels of foreign debt to feed domestic consumer debt, and that the state apparatus enabled this to happen. Ongoing structural volatility led to the 1994 peso devaluation that then caused the peso value of the banks' foreign denominated debt obligations to rise abruptly. The over extension of large holding group debt was exposed, leading the banking system into crisis by 1995 (BdeM, 1996: 1). Official accounts blame the crisis on weak state regulation and inexperienced Mexican bankers, but this misses the root problem. ${ }^{7}$ The 1994 peso crisis and 1995 banking crisis arose with the political decisions to liberalize the Mexican economy since de la Madrid and with the associated accumulation strategies of domestic capital that have had to manage increasingly high debt levels (Soederberg, 2004: 48). Rather than breaking with market discipline, the PRI bank rescue preserved neoliberalism's relations of power in a form institutionally specific to Mexico.

The 2001 Turkish banking crisis is also rooted in the political decisions and competitive imperatives shaping its society's transition to neoliberalism. Backed by the military, Turgut Özal's Motherland Party (ANAP; Anavatan Partisi; 1983-1991) spearheaded market-oriented restructuring (Balkan and Yeldan, 2002). Once the initial export-led boom subsided after 1987, demands by domestic capital and state authorities for greater access to foreign capital grew. More money was needed to sustain debt-led accumulation strategies and to service growing state deficits. The interests of state and domestic capital culminated in the 1989 capital account liberalization decree (Akyüz and Boratav, 2003: 1551). This then encouraged the internalization of foreign currency and Turkish lira (TL) substitution within Turkey's already unstable and inflation-prone economy. By releasing financial forces, the ANAP government had institutionalized a situation where it could only rollover public debt by way of costly and speculative flows of foreign capital, much to the benefit of those who own and control money capital. Economic instability resulted, and according to the World Bank (2005: 1), the 'long-predicted financial crisis finally struck' in 1994. 
A banking crisis did not follow immediately from the 1994 Turkish crisis as in Mexico, but the 2001 banking crisis is tightly related. For some, the 1994 crisis was not severe enough to stimulate the political will needed to reshape Turkey as a more competitive society and avoid the 2001 crisis (Öniş, 2009: 413). For others, 1994 was an omen of deeper problems to come, beginning with the 1989 financial opening and continuing through to the 2001 meltdown (Cizre and Yeldan, 2005). In different ways, both point to ongoing volatility within Turkey, compounded internationally by the 1997 Asian meltdown and 1998 Russian crisis. As only one example of volatility, the coalition government of Bülent Ecevit's Democratic Left Party (DSP; Demokratik Sol Parti) had pulled eight failed banks into the Saving Deposit Insurance Fund (TMSF; Tasarruf Mevduatı Sigorta Fonu) from 1997 to 1999, socializing about 8 per cent of all banking assets and risks (World Bank, 2003: 52).

This volatility, if not immediate crisis, led to the unrolling of the IMForchestrated December 1999 disinflation program whose political intent was to better institutionalize finance-led neoliberalism in Turkey. The program's decision to pre-announce exchange rates (via a crawling peg) attempted to encourage more stable flows of foreign capital. In the first 10 months of 2000, this sparked a net inflow of $\$ 12.5$ billion (Akyüz and Boratav, 2003: 1554). However, the flows were almost entirely debt-creating with the risks concentrated in commercial banks that borrowed in shortterm foreign currency and then lent in longer-term TL terms. This resulted in grave credit maturity mismatches and foreign currency open positions (BDDK, 2002).

The first wave of the crisis hit in late October 2000 as three more Turkish banks failed. Fearing instability, money capital began to flee from Turkish markets, which in turn pressured the government into injecting billions into the financial sector to avoid collapse. The December 2000 IMF relief package then delivered $\$ 10$ billion in support, seemingly stabilizing matters. Yet investor confidence in Turkey's capacity to sustain its rising public debt remained shaken. Moreover, the 2000 crisis exposed the government's problematic exposure to billions of dollars in unpaid official 'duty losses' held in the state banks (BDDK, 2003: 10). The duty losses were claims on the Treasury (BHM; Başbakanlık Hazine Müsteşarlıgı) for government-assigned subsidized lending and the interest accrued (TBB 2001). The claims show as state bank assets, but not as budget liabilities (OECD, 1999: 57). State bank duty losses initially supported post-war developmental priorities. Since the 1990s, market-oriented yet cash-strapped governments used duty losses to smooth Turkey's debt-led neoliberal restructuring without visibly incurring official debt - that is, until the 2001 crisis. The final trigger to the 2001 banking crisis occurred on 19 February. A theatrical quarrel between Prime Minister Bülent Ecevit and President Ahmet Necdet Sezer sparked nearly $\$ 5$ billion in capital flight, or a quarter 
of Turkey's $\$ 20$ billion in reserves. The bank rescue that followed this crisis and Mexico's are explored next.

\section{THE TENDENCIES OF NEOLIBERAL BANK RESCUES IN MEXICO AND TURKEY}

One way historical materialist analysis distinguishes itself from liberal and institutionalist analyses is by internalizing the social relations of power and class specific to different phases of capitalism as underlying causal factors. That governments have authored new policies based on fiscal austerity, labor flexibility, privatization, financial opening, and trade liberalization remains of vital concern. Likewise, that neoliberalism has become synonymous with the individualist ideology that no matter the social, political, economic, or ecological problem, more exposure to the competitive world market can resolve it is also of concern. Yet, analysis remains neither at the level of institutions nor that of individuals alone, but instead seeks an integrated understanding based in the social relations of class, capital, and state (Ollman, 1993; Poulantzas, 2000). From this perspective, the emergence of neoliberalism since the 1980s has rested first on the defeat of popular classes' and organized labor's capacity to resist structural adjustment at home and second on the re-asserted dominance of finance globally (Duménil and Lévy, 2001; Panitch and Gindin, 2004). While there is evidence of aggregate growth, development under neoliberalism has been characteristically uneven and prone to financial crises, especially for middle-income countries (Kiely, 2007; Soederberg, 2004).

Yet financial crises have not severely delayed the consolidation of neoliberal strategies, but have instead opened up new market-oriented restructuring possibilities once thought improbable or impossible (Cypher, 1989; Marois, 2005; Öniş, 2009). The crisis-driven bank rescues in Mexico and Turkey have then institutionalized specific and bolder forms of financeled neoliberal social rule shaped by the universalizing pressures of world market competitive pressures. Three interrelated tendencies illustrate how this has been to the benefit of finance: (a) the socialization of risk and debt, (b) the rationalization of the banking sector, and (c) the internationalization of the financial apparatus. Governments undertake these measures because they see them as necessary to preserve market-oriented strategies of development.

\section{The socialization of debt and risk}

The socialization of debt and risk represents how market-oriented governments - under structural pressure from finance and fear of economic collapse - tend to accept ownership of and responsibility for financial risks that have gone bad and instigated systemic crisis. Governments socialize financial risks to re-invigorate finance-led capitalism. Mainstream 
accounts understand that the fiscal costs of crises represent transfers from present and future taxpayers to present and future beneficiaries (Furceri and Mourougane, 2009: 28). Yet they ignore how rescues re-institutionalize structurally unequal relations of power between finance (the beneficiaries) and the laboring classes (the taxpayers).

In Mexico as the 1995 banking crisis unfolded, the Ernesto Zedillo PRI government coordinated its response through the BdeM and the Banking Fund for the Protection of Savings (Fobaproa; Fondo Bancario de Protección al Ahorro). Because the funds collected by Fobaproa to date fell short, the PRI absorbed the cost of rescue into the Executive budget without public consultation (SHCP, 1998: 33). At the time, the PRI claimed the rescue would cost about 5.5 per cent of 1995 gross domestic product (GDP) (BdeM, 1996: 8). In national discourse, the Ministry of Finance and Public Credit (SHCP; Secretaría de Hacienda y Crédito Público) framed the bank rescue not as saving a few private bankers, but as necessary for the benefit of all Mexicans (SHCP, 1998: 21).

The first actions taken involved injecting immediate US dollar liquidity into the troubled Mexican banks and a Temporary Capitalization Program (Procapte) to help failing banks reach an 8 per cent capital to asset ratio (SHCP, 1998: 34-5; BdeM, 1998: 156). The political intent was to restore immediate social confidence in the banks. Another program aimed to stretch out and restructure the individual debts of fisheries, families, small and medium-sized enterprises (SMEs), and so on (SHCP, 1998: 35; OECD, 2002: 155). Rising interest rates and falling personal incomes meant this program was practically ineffectual for the average debtor (Avalos and Trillo, 2006: 25 ), yet the goal of encouraging individuals to collectively honor their debts to the banks is clear. The most substantial socialization measure, however, involved the PRI intervening directly in the interests of finance through the permanent recapitalization program. The state absorbed the banks' bad debts with 10-year bonds that were non-negotiable and capitalizable every three months (SHCP, 1998: 38; OECD, 2002: 155). The bankers accepted the state bonds, and the Mexican public's capacity to honor them.

By early 1998 , the cost of socialization had grown to $\$ 60$ billion or around 15 per cent of 1998 GDP - five times the $\$ 12$ billion received for bank privatization just a few years earlier. The PRI recognized Fobaproa could not independently redeem the 1995 bonds as they became due, thus threatening economic stability. This prompted President Zedillo to ask Congress to officially absorb all Fobaproa debt in March 1998 (SHCP, 1998: 51-2). In a society rocked by the post-NAFTA Zapatista uprising, lingering fury over the first bailout, growing levels of poverty, ongoing government corruption, and the recent December 1997 peasant massacre in Acteal, this unleashed a political maelstrom. The PRI no longer enjoyed the political dominance it once had in Congress. The Party of the Democratic Revolution (PRD; Partido de la Revolución Democrática) had also obtained the 
names of Fobaproa beneficiaries who would again benefit from the Zedillo plan. A few were among Latin America's billionaires. Many others were generous PRI contributors (Rosen 1998). Nine months of political debate and public outcry ensued. In December 1998, the PRI pulled together a deal with the National Action Party (PAN; Partido Acción Nacional) and pushed through a modified debt socialization plan. The costs of servicing the debt would be included in Mexico's annual budget, a measure only made possible by diverting tax revenues away from social spending (Stallings, 2006: 190).

Ten years on, the IMF (2006: 28) has expressed concern over the $\$ 100$ billion in accrued debt (nearly 20 per cent of GDP). In negotiations with the now majority foreign-owned banks, the government has allowed the banks to exchange the old bonds for new financial instruments (Mannsberger and McBride, 2007: 327). However, popular discontent has not subsided against either the PRI or the PAN evidenced in part by a collective of bank workers that supported the PRD candidate - under the banner of 'Bancarios por López Obrador' (Bank Workers for López Obrador) - during the 2006 presidential elections.

In Turkey following the February 2001 crisis, the Ecevit DSP coalition held together more by the dire economic circumstances than by any political affinities - named longtime World Bank executive, Kemal Derviş, as the new Minister of the Economy to help organize the 2001 bank rescue. The coalition gave Derviş broad powers to do so, including control over the Banking Regulation and Supervision Agency (BDDK; Bankacıllk Düzenleme ve Denetleme Kurumu). By mid April, he announced the Transition to a Strong Economy (TSE) program designed to renew Turkey's openness to the world market. At the heart of the TSE rested the May 2001 Banking Sector Restructuring Program (BSRP) to be carried out through the BDDK. Derviş portrayed the BSRP in national discourse as capable of eliminating financial distortions and as promoting an efficient, globally competitive, and stable banking sector (BDDK 2002). This first meant socializing the vast amounts of risky debt and duty losses held by the banks in Turkey.

The DSP coalition had already transferred $\$ 6.1$ billion from the BHM to the TMSF in October 2000 to cover the already failed banks (OECD, 2001: 206; World Bank, 2003: 52). This included over $\$ 2$ billion in support for foreign banks. As the 2001 crisis unfolded, the DSP disregarded the legislated deposit coverage limits established in June 2000 and accepted responsibility for 100 per cent of the losses 'with the purpose of protecting the banking system' (BDDK, 2003: 20). The final rescue tally amounted to $\$ 47.2$ billion - or just over 30 per cent of 2002 GDP (BDDK, 2003: 6). ${ }^{8}$ Nearly $\$ 22$ billion liquidated the state banks' duty losses and the other $\$ 25$ billion covered the failed private banks. The Turkish public undertook responsibility for $\$ 44.5$ billion of this and the private banks $\$ 2.7$ billion. 
The socialization of bad debt and risk represents an initial, compelling, and necessary political step to rescue the banks if and only if the PRI and DSP wanted to remain within the confines of market-oriented capitalist development. By managing this risk at home, state financial authorities contributed to managing the competitive world market.

\section{The rationalization of the banking sector}

In the rescue process, state authorities also tended to take responsibility for rationalizing the banking sector in line with neoliberal developmental strategies. While seemingly at odds with the principle, state intervention is meant to upgrade the market-oriented organization of the banks. In Mexico and Turkey, this has involved IFI-mediated and government-authored regulatory changes, forced mergers, bank takeovers, and the internalization of foreign bank capital.

The Derviş BSRP policy response to the 2001 Turkish crisis included more restrictive bank regulatory and supervisory measures meant to stabilize market-oriented finance. The IMF had taken the lead in proposing the reforms but - according to Faik Öztrak, ${ }^{9}$ a Cumkuriet Halk Partisi; Rebulican People's Party (CHP) member of parliament, former Subsecretary of the BHM, and architect of the 2001 crisis restructuring plan alongside Derviş - the reforms were not imposed but prepared by the Turkish bureaucracy, even though it is in the interests of Turkish politicians to suggest otherwise. The DSP measures involved amending the 1999 Banking Law to impose tougher capital requirements, stricter credit limits, larger non-performing loan provisions, and so on (BDDK, 2001). New merger and acquisition tax incentives aimed to reduce the number of banks (BDDK, 2003: 66). Corporate and tax legislation reorganized once combined financial-industrial groups into separated financial and corporate conglomerates. The rules around related-lending and associated loan limits were stiffened. These legal changes forced Turkish holding groups to pursue banking as a separate business in its own right. ${ }^{10}$ The BSRP also encouraged the entry of foreign bank capital via higher liquidity and capital adequacy requirements, and thus the formation of domestic-foreign joint banking ventures (the Basel accords discussed below). In a banking system with low liquidity, the policy compelled domestic banks to seek out foreign capital.

The 2001 crisis also provided an opportunity for the DSP to rapidly restructure the state banks according to a market-oriented logic. The coalition annulled nearly 100 regulations and, in doing so, arrested the possibility of any future political channeling of state bank resources, be they developmental or neoliberal in orientation. The coalition then merged the state-owned Emlak Bank into Ziraat Bank as the BDDK re-crafted the three remaining state bank operations in line with profit imperatives. State 
bank managers have since pursued European Union (EU) harmonization in preparation for eventual privatization.

The 1995 Mexican rationalization process has striking similarities. As in Turkey, financial policy changes re-articulated how Mexican banks operated within the competitive world market by way of new supervision requirements, bank regulations, capital adequacy, and limited deposit protections (SHCP, 1998). State-led rationalization likewise re-organized the banks. From 1995 to 1997, Fobaproa took over 13 mostly smaller failed banks, then closed and/or re-sold them to other domestic or foreign banks. The PRI also viewed the entry of foreign bank capital favorably. In February 1995, Zedillo modified the 1990 Credit Institutions Law to encourage domestic-foreign alliances. According to the BdeM (1996: 133, 230-5), foreign capital would help improve systemic efficiency, restore stability, and increase the banking sector's capital base. The changes enabled foreign investors to take majority control of all but the three largest banks (Tschoegl, 2004: 59). Lingering restrictions and ongoing economic instability slowed foreign interest until all ownership barriers were removed in 1999, releasing a flood of foreign bank capital into Mexico.

The tendency towards post-banking crisis rationalization is tantamount to the government putting its 'house in order', to which the Governor of the TCMB, Durmuş Yılmaz (2007), plainly alludes. In both Mexico and Turkey, this 'order' has meant the restructuring of the banking sector around financial imperatives in a manner consistent with their state's subordinate positions within the world market.

\section{The internationalization of the state's financial apparatus}

The internationalization of the state's financial apparatus is the third tendency, and it has a dual character. On the one hand, internationalization involves government elites and state managers accepting responsibility for managing their own domestic capitalist order in such a way that they also contribute to protecting the international capitalist order (Panitch and Gindin, 2003: 17). On the other hand, internationalization involves these same actors insulating the state's financial apparatus from domestic politics according to international norms. The sine qua non of policy credibility and internationalization today, for example, involves central bank independence and inflation targeting (Mishkin, 2009).

Internationalization in Mexico took firmer root with the 1994 NAFTA, and has accelerated since the 1995 banking crisis. In the lead up to NAFTA, the PRI had already granted the BdeM independence. Then in response to the 1995 crisis, the PRI merged the once separate National Securities and National Banking commissions into one - the National Banking and Securities Commission (CNBV; Comisión Nacional Bancaria y de Valores) to set the banking sector on a better footing at home and in relation to 
the world market (BdeM, 1996: 133). Zedillo granted the CNBV greater independence in his 1998 reforms, which fell short of full autonomy. The government also granted the $\mathrm{CNBV}$ greater powers to liaison with foreign regulators, whose relations are formalized in joint international Memorandums of Understanding (MU) (IMF, 2007a: 15). The 1998 reforms also replaced Fobaproa with a new bankers' fund responsible for insuring foreign and domestic banks alike - the Bank Savings Protection Institute (IPAB; Instituto para la Protección al Ahorro Bancario) (BdeM, 1999: 232). As the 1995 crisis settled out and foreign ownership restrictions disappeared in 1999, there was a far greater need to bring banking regulations within international norms, according to a high-ranking SHCP director. ${ }^{11}$ The Vicente FoxPAN government responded in its National Development Finance Program (2002-06), which pursued compliance with the Bank for International Settlements (BIS) Basel 25 core banking principles (IMF, 2006). The current PAN President Felipe Calderón's 2007-12 National Development Plan (NDP) continues to institutionally privilege financial stability by enhancing the protection of property rights, promoting financial competition, and enhancing state financial regulation.

The Turkish government's 2001 bank rescue was also shaped by a form of internationalization committed to an order that, in the words of Derviş, separates 'the economic from the political' (in TBB, June 2001; also see Cizre and Yeldan, 2005: 390). As one response to the 2001 crisis, the DSP coalition granted the TCMB formal independence (Y1lmaz, 2007: 3). The coalition then augmented the autonomy and regulatory power of the BDDK and the TMSF (BDDK, 2001). The BDDK has assumed responsibility for negotiating international MUs that formalize relations between the BDDK and other foreign bank supervisory agencies like Mexico's CNBV (BDDK, 2003: 68-9). The BDDK also has the important task of analyzing and implementing the Basel II accords intended to bring Turkish risk management and capital adequacy standards in line with international norms (TBB, 2005: 23)..$^{12}$

Upon coming to power in 2002 and at the headwaters of an economic expansionary phase, the Justice and Development Party (AKP; Adalet ve Kalkınma Partisi) enhanced TCMB independence. The AKP did so by bringing its structures and duties closer to international standards and, most significantly, by legislating price stability and inflation-targeting as TCMB imperatives (TBB, 2005: 25). The TCMB can no longer undertake any initiative that interferes with these imperatives. ${ }^{13}$ At the same time, Turkey's commitment to the EU Customs Union and ongoing accession talks form the touchstone of domestic financial policy formation, according to Ersin Özince (2005), chair of the Banks Association of Turkey (TBB; Türkiye Bankalar Birliği). The 2005 Bank Law was framed with EU accession in mind, which was presented as an opportunity to strengthen institutional capacity through internationalization (BDDK, 2006). Most banking 
activities today are harmonized with market-oriented EU directives and international best practices (TBB, 2007: I-8).

While credible in the eyes of liberal political economy, internationalization tends to institutionalize firewalls between (a) the flows of money in a society and the financial apparatus and (b) the public's influence over these. Whether you refer to this process as de-politicization (La Porta et al., 2002) or as establishing external policy anchors (Öniş, 2006), internationalization militates against public representation shaping the actions of finance (Grabel, 2000: 7). Furthermore, internationalization has shaped a more robust financial apparatus more capable of managing finance-led accumulation, contrary to 'hollowed out' accounts of the neoliberal state.

Socialization, rationalization, and internationalization are constitutive of the Mexican and Turkish institutionalized form of finance-led neoliberalism. While the weaknesses of individual banks are exposed, the strength of finance in society is revealed: the financial risks specific to the current phase of capital accumulation that drive recurrent crises have become the collective responsibility of present and future generations of Mexicans and Turks. Yet popular sectors have been unable to penetrate the bank rescue and reform process.

\section{THE TENDENCIES OF BANK CAPITAL IN MEXICO AND TURKEY}

The tendencies of bank rescues seen above occur within the structure of the world market wherein individual banks coexist and compete. In contrast to liberal frameworks that see the world market as a timeless economic sphere of individual competition and redistributive justice (Vanberg, 2005), the world market is here defined as a real abstraction that has emerged historically in the context of capitalism and is composed of universal flows of money, credit, and capital and therefore of unequal and exploitative sets of class-based social relations of power. As Oliver Nachtwey and Tobias ten Brink (2008: 45) write on the world market, "The form of value (money, capital) and the law of value (the market) impose a particular logic upon people and make a particular form of rationality plausible to them - a pressure that takes effect behind the backs of the subjects.' In the cases of Mexico and Turkey, bank capital has historically tended towards what Marxists argue are structural features of capitalism, namely (a) the centralization and concentration of capital and (b) the intensification of competitive imperatives ( $c f$. Sweezy, 1970: 254-62), and these often accelerate following periods of crisis.

\section{The centralization and concentration of bank capital}

The centralization of bank capital is a historical-structural process of combining pre-existing but separate banking institutions through such things 
as mergers and the formation of holding groups. Centralization is driven by world market competition and enabled by the availability of credit (Marx, 1990: 776-80). The process can occur rapidly and result in more powerful combinations of bank capital. The concentration of bank capital is related but distinct, and it refers to how the accumulated quantity of capital controlled by a single bank tends to become greater with time. The greater the concentration of capital, the larger the possible scale of activity aimed at increasing the amount of accumulated capital. However, because capital is conceived not simply as a thing or input as in neoclassical economic theory but as an unequal social relation of power between capital and labor, the greater the concentration of capital the greater the power of those who own and control it within capitalist society. In the case of banking, there is a dual character to the concentration of capital. On the one hand, concentration occurs at the level of ownership group, including state, private domestic and foreign bank ownership. On the other hand, concentration occurs at the level of individual banks. While centralization and concentration are structural tendencies, contingent counter-tendencies such as domestic political realities and economic crises - can offset, reverse, or intensify them depending on the circumstances.

In post-war Turkey, many small private banks were established early on and failed. More stable state-owned and larger domestic banks emerged later alongside smaller foreign banks such that by the 1960s there were about 50 banking institutions (BYEGM, 2005; TBB, 1964). State regulations then promoted the centralization of smaller private banks into the larger Turkish holding groups to augment domestic credit availability for industrialization. By 1980, the number of banks had fallen to 39 (TBB, 1981). Financial liberalization during the 1980s subsequently encouraged banking de-centralization and numbers increased to 62 by 1999 (TBB, 1981-2000). Nevertheless, the large Turkish holding groups had already begun acquiring control over most of the private banks (Isık and Akçaoğlu, 2006: 5; Ercan, 2002: 30). As in Mexico, holding groups with banks at the core of operations gained an exceptional competitive advantage because they could more easily access credit and channel bank profits into the group's wider activities (Öncü and Gökçe, 1991: 106; OECD, 1999: 126-7; Ercan and Oguz, 2007: 181). In the public sector, state managers actively centralized the capital of state-owned banks so they could also better respond to the demands of capital: from 1980 to 1999, 11 state banks became four - Ziraat, Halk, Vakif, and Emlak - through minor privatizations, mergers, and closures (TBB 1964-2000). Following the 2001 banking crisis, government policy again drew on centralization as a tool of economic stabilization. By way of mergers, failures, and state rescues, bank numbers dropped from 62 to 33 between 1999 and 2006 - all of which were private banks except for Emlak Bank (TBB, 2000; TBB, 2007: I-35). The 2001 bank rescue did not change the fact that holding groups owned most the banks, 
but tighter regulation and foreign bank partnerships erected stronger firewalls between the core holding group and its banking operations.

The concentration of capital in Turkish private banks has grown alongside centralization. Since 1923, private domestic, foreign, and state-owned banks have co-existed. By the mid 1960s, the state banks had gained control of about 64 per cent of all bank assets, private domestic 27 per cent, and foreign 4 per cent (TBB, 1999). By the late 1990s, state bank assets had contracted to about 39 per cent as private domestic bank assets expanded to just above 50 per cent. Foreign control remained stagnant around 3.5 per cent, but with the prospect of EU accession since 2004, it began to swell. Whereas in 2005 foreign banks controlled just 5 per cent of the sector, this more than doubled to 12 per cent by 2006 and climbed again to 15 per cent presently (TBB, 2007L I-39; 2009: I-41). Estimates that include minority foreign-held shares in the Istanbul Stock Exchange suggest foreign ownership is now over 35 per cent.

The concentration of capital within individual banks has also tended to increase, especially since 2001. By the early 1990s, the five largest banks controlled 54 per cent of all banking assets and the top 10 banks 75 per cent. Liberalization through the 1990s, however, nurtured de-concentration for a time: the top five banks controlled just 46 per cent of assets and the top 10 68 per cent by 1999 (TBB, 2000). This reversed after 2001 only to supersede 1990 levels. Within a year, the top five controlled 58 per cent and the top 10 81 per cent of all assets. Presently, the top five banks control 62 per cent and the top 1086 per cent (TBB, 2009: I-41). Interestingly, the state banks remain within the top 10 and continue to control about a third of banking assets.

In the case of Mexico, the number of post-war banking institutions ballooned from less than 40 to 105 from 1940 to 1971 (Bátiz-Lazo and Del Angel, 2003: 344; Aubey, 1971: 26). The large quantity should not obscure how most financial institutions had become centralized within large Mexican holding groups. By the mid-1960s, six groups owned 44 commercial banks and 21 financieras (investment-type banks) (Aubey, 1971: 26). The holding groups used their banks' savings to channel resources into their non-bank affiliates and to boost their market power, much as in Turkey (Del Ángel-Mobarak, 2005: 46). Following the near collapse of the sector in 1982 and bank nationalization, the de la Madrid PRI government centralized the existing 58 nationalized banks into 18 by 1986 and organized them along local, regional, and national lines to promote stability and respond to the demands of capital. Following the 1991-92 bank privatizations, however, the number of banks again mushroomed to 41 by the time the 1995 banking crisis hit. These then fell to 36 by 2000 and to 31 by 2006 due to banking failures, mergers, and the reticence of Mexican authorities to grant new banking licenses (CNBV, 2001-2008).

Prior to the 1995 banking crisis, bank capital was almost wholly concentrated in the hands of Mexicans (including state ownership from 1982 
to 1992). Shortly thereafter an initial break in Mexican control occurred. Just over $\$ 1$ billion in foreign bank capital entered from Spain, Canada, the $\mathrm{UK}$, and the US over the next four years. However, with the removal of all foreign ownership restrictions in 1999 - over and above what had been negotiated in the 1994 NAFTA Chapter 14 appendices - foreign banks were poised to assume control in the new millennium. Between 2000 and 2002, just over $\$ 20$ billion in foreign bank capital entered. Whereas Citibank had been the lone foreign bank in Mexico since 1929, there were 18 foreign and 18 private domestic banks by 2002 (OECD, 2004: 310). Mexico today has among the highest concentrations of bank capital under foreign control in Latin America, sitting around 85 per cent. ${ }^{14}$

Bank capital concentration is also evident in how most banks are controlled within a few powerful financial groups (BdeM, 2007: 79, 83). Whereas six Mexican financial groups informally controlled about 73 per cent of all financial sector resources in the mid-1960s - including many dozens of separate banks and other financial institutions - nearly 97 per cent of all bank capital and 84 per cent of all mutual fund assets are concentrated within formally incorporated financial groups today (Aubey, 1971: 26; BdeM, 2007: 50). The six largest groups control over 85 per cent of all bank assets (BdeM, 2007: 51). The largest bank, Spanish-owned BBVA Bancomer, controls over 27 per cent of bank assets, the top two banks, which includes the US-owned Citibank-Banamex, control 44 per cent of all private sector credits and 60 per cent of all mortgages (CNBV, 2008: 43). As universal banks, their operations have spread to virtually all aspects of finance (IMF, 2007a). The monopolistic position of foreign banking giants have raised concerns within the Calderón administration, whose 2007-12 NDP encourages market-based solutions to diffuse bank concentration, and within the IMF (2009a), which has raised red flags over the possible impact of foreign affiliate failure owing to the 2008-09 financial crisis.

In Mexico and Turkey, bank centralization and concentration have tended towards the greater private and foreign control of bank capital that is concentrated in larger and fewer institutions. In consequence, finance has gained a stronger position of power in society. This too has led to more intense competitive imperatives.

\section{The intensification of competitive banking imperatives}

Intensification refers to a structural acceleration in the competitive imperatives acting upon bank institutions and workers, individually and collectively. In the post-war period, intensification typically involved the extension of multi-branch banking in Mexico and Turkey, but government policy also mitigated intensification pressures to protect bank profitability and domestic stability. This state-led model of banking came under material and ideological pressure in the late 1970s, however, as a form 
of so-called financial repression (Shaw, 1973; McKinnon, 1973). With the transition to neoliberalism, liberal political economists have celebrated intensification as the triumph of market-discipline and egoistic individual choices, which result in the most just form of allocating society's resources. Institutional political economists have likewise encouraged intensification so long as it follows the right sequencing of events and builds the institutions necessary to promote virtuous investment cycles and a more equitable distributional compromise between capital and labor (Öniş, 2009). By contrast, I focus on the ways in which intensification is experienced in the lives of people and their communities - through bank jobs, productivity demands, profit imperatives, and so on - that has been more often overlooked. ${ }^{15}$

In the case of Turkey, the ratio of bank assets to gross national product more than doubled from 31 to 80 per cent from 1980 to 2000 (TBB, 2000). The number of foreign, state, and private domestic bank branches, however, remained practically flat. Among the private banks, moreover, employee numbers increased by less than 5 per cent, and this is despite overcoming the state banks in overall asset control (shown above). Fewer workers handling more bank capital helped to drive productivity gains and contribute to the more than doubling of the private banks' return on assets (ROA) profit ratios, which grew from about 1 per cent before the 1980s to over 2 per cent by the late 1990s (TBB, 1999). ${ }^{16}$ In response to Prime Minister Turgut Ozal's liberalization efforts, the Turkish private banks also turned to leveraging more capital to earn higher (and riskier) returns on equity (ROE) profits (this too was a prime factor leading to de-centralization via new entries into the market). ROE grew from about 35 per cent before 1980 to just over 60 per cent in the late 1990s (TBB, 2000). Whereas a bank's ROA is the fundamental measure of its core situation, ROE shows what happens when owners leverage a bank's fundamentals by taking on debt. If ROA is falling and ROE increasing, then a bank is likely headed for problems.

The culmination of leveraged and high risk bank returns amidst domestic political and economic instability and open capital accounts contributed to the 2001 bank crisis and the collapse of many banks. As noted, the 2001 BSRP, among other measures, imposed higher reserve requirements in response. This enabled Turkey to keep its neoliberal development strategy alive, but one modified by crisis. ROE fell to about 14 per cent by 2003 and to just under 20 per cent by 2008 (TBB, 2003-2008), suggesting less debt-led risk. Yet the private banks' ROA ratios have not suffered since the 2001 crisis and have remained in the 2 per cent range rising to a relatively high 2.4 per cent by 2008. The new foreign bank entries have achieved similar levels, with 2008 ROA at 2 per cent and ROE at just over 15 per cent. How is it possible, when seemingly rather contrary to liberal orthodoxy, that stiffer regulations at home amidst more aggressive world market competition can result in higher profits? 
The Turkish state-owned banks are instructive. By the late 1990s, the state banks had lost their dominant position to the private banks yet ROA measures remained solid at around 1 per cent. This, too, is during the 1980s and 1990s when the government used the state banks for unpaid duty losses and as receptacles for several failed private banks. The latter meant more state bank employees. The handling of more employees while responding to mandated developmental missions (that had become neoliberal in orientation since the 1980s) goes some way to explaining historically why state banks had comparatively lower profits than the private banks. Moreover, while profitability was never the mandated objective of any state bank, this changed in 2001 when the BSRP mandated profitability as an operational imperative. State bank managers responded by cutting the number of Halk and Ziraat employees by over 40 per cent and reducing the number of branches by over 30 per cent. As a result, the assets managed per state bank employee doubled from $\$ 0.7$ million in December 2001 to $\$ 1.4$ million by August 2003 and the assets handled per branch nearly doubled from \$13.9 million to \$26.1 million (BDDK, 2003: 13-14). State bank ROA exploded, reaching 2.2 per cent by 2003 and 2.8 per cent by 2008 without the more risky and debt-based ROE measures going beyond the 20 to 25 per cent range (TBB, 2004-2008). ${ }^{17}$ State bank profitability is linked to more intense demands being placed on workers.

There are important similarities with the Mexican banks and how, under state control during the 1980s, state financial authorities also intensified the demands placed on bank workers. For one, the PRI encouraged a parallel system of private market-based financial institutions to compete with the state banks. At the same time, financial authorities restricted the growth in state bank branches to merely 0.05 per cent despite the number of potential bank users increasing by 33.9 per cent between 1982 and $1988 .{ }^{18}$ This pushed up labor productivity during a period when the PRI was enforcing real wage reductions for bank workers. When bank privatization was announced in 1990, the bank unions welcomed it because of the foregoing decade of state-led austerity and demanded a 100 per cent wage increase in return for their support for privatization (Weiser, 1990). The 1991 to 1992 bank privatizations did not do much to improve conditions for bank workers. However, the new bank owners did find themselves thrust into a highly competitive setting. One response fed on the past decade of state austerity, and sparked a bankers' race to capture hitherto unbanked Mexicans' savings: the number of bank branches postprivatization exploded by nearly 36 per cent. The new owners then sliced the number of bank workers by 13 per cent (OECD, 1998: 187-90).

The pattern remained consistent following the 1995 bank rescue. From 1996 to 2000, the number of new branches expanded by another 12 per cent as growth in new employees was restricted (OECD, 2004: 304-7). This 
form of intensification delivered remarkable results. Bank owners nearly doubled worker productivity: whereas in 1994 Mexican banks averaged 29.25 employees per branch this fell to 18.13 per branch by 1998 and to 15.63 by 2000 . This level of productivity was maintained in the latest economic expansionary phase from 2000 to 2007 and with the entry of foreign banks. Bank branches grew another 25 per cent, which was matched this time by employee expansion at just over 25 per cent (CNBV, 2001-2008). Since 2000, ROA grew more than two and half times from 0.94 to 2.75; ROE ratios doubled from 9.69 to 19.93 (CNBV, 2001-2008). According to the Deputy Governor of the BdeM, José Sidaoui (2006), the growth in bank profits is closely tied to reductions in bank employees.

To illustrate that renewed bank profitability is tied to intensified productivity demands is not to ignore certain other developments in the Mexican and Turkish banking sectors. Rather, it is to highlight the social relations of power inherent in banking. To be sure, capital to asset ratios have improved steadily following crisis and with the entry of foreign bank capital. Most Mexican and Turkish banks have been in the range of 14 to 16 per cent since 2001 and remain so (IMF, 2009a: 40; TBB, 2009). In Mexico, foreign banks have also begun to re-enter the mortgage market, which has seen an expansion in the home property base driven by the state provider, Infonavit (IMF, 2007b: 25). In both countries, bringing inflation and interest rates under control has enabled banks to offer longer-term fixed-rate products thus improving mortgage affordability. In Turkey, the state-owned Emlak Bank continues to support SMEs. Consumer credit is also more widely available.

While in individual cases there are some benefits, so too are there some problems experienced collectively. For one, higher capital adequacy levels are a reflection of Mexico and Turkey's continued subordination within the international hierarchy of states. Financial authorities must ensure the banks are prepared for volatile conditions in a way high-income countries like the US or UK typically have not. Greater consumer access to credit has also come at an extraordinary cost for the average Mexican and Turk where interest rates far exceed those offered by many of the same global banks operating in high income countries. Likewise, the entry of foreign banks has at times contributed to capital adequacy and increased the availability of credit, but this often comes with unreasonably high costs and without the benefit of backward linkages from financial to productive ventures or from more developed urban areas to poorer rural areas (Eres, 2005; Mannsberger and McBride, 2007; Gültekin-Karakaş, 2008; Beck and Martinez Peria, 2008).

As a structural feature to capitalist development, we see the intensification of competitive imperatives in the banking process. Characteristically of neoliberal class relations, however, intensification has translated into demanding more from labor. Tendencies towards bank centralization and 
concentration also imply that intensification is also occurring at a larger, and more powerful, scale.

\section{CONCLUSION}

Looking back to early 2009, the G-20 released a Report in the lead up to its April meeting in London. Titled The Road to the London Summit: The Plan for Recovery, ${ }_{1}^{19}$ it called on world leaders to make three commitments to help rescue global economic growth. First, to take whatever action is necessary to stabilize financial markets and enable families and businesses to get through the recession. Second, to reform and strengthen the global financial and economic system to restore confidence and trust. Third, to put the global economy on track for sustainable growth. Underlying these commitments rests a cardinal warning: according to US Federal Reserve Chair Ben Bernanke, any new regulatory reforms must not 'forfeit the economic benefits of financial innovation and market discipline'.$^{20}$ The 'sacred cows' of financial policy must not die and the containment of crisis is not tantamount to a permanent deviation, according to Aslı DemirgüçKunt and Luis Servén (2009: 45).

Six months beyond the London G-20 Summit, a full year on from the collapse of Lehman Brothers, and despite the world leaders' strong rhetoric, many recognize that there have been no structural deviations in financial regulation and that market discipline endures. This is not to say the rescue cum stimulus packages have not been unprecedented and that they have had no effect. Indeed, the US and European governments have socialized unheard-of quantities of bad private risk and debt, aggressively rationalized the domestic banking sectors via forced mergers, closures, and so on, and committed themselves to new heights of internationalization, most visibly through the G-20 meetings. In the process of rescue, big global banks have become bigger through the centralization and concentration of capital. Far from mitigating the competitive imperatives leading to the 2008-09 crisis, it seems the rescues have intensified the social and structural conditions amenable to another crisis occurring. Most G-20 governments have supported an astonishing rebound in bank profitability by allowing huge differentials between the central bank base rate and individual banks' lending rates. The groundwork for the banks' return to profitability was first laid in the wake of crisis by bank managers making thousands of employees redundant and by closing bank branches. Yet the G-20 September 2009 meeting in Pittsburgh at best strongly encouraged bankers to reign in the most profligate bonus structures in order to bolster capital reserves (and to skirt renewed popular discontent). Regardless of the fact that the sub-prime crisis precipitated one of the worst economic recessions in over five decades, structural change has failed and the power of finance prevails. 
At a conceptual level, we can begin to see that the tendencies of emerging market bank rescues seen in Mexico and Turkey resonate rather forcefully with responses to crisis today. We can also begin to see that the universalization of finance-led neoliberal social rule in institutionally specific and differentiated forms experienced in Mexico and Turkey's rescues also apply today in similar ways. On the one hand, world leaders, national policy-makers, and IFIs have given more attention than in the past to the differentiated impacts and responses to the 2008-09 crisis. Case in point is the historic G-20 call to multilateralism. The IFIs have at the same time tolerated a range of heterodox responses to crisis unseen for decades. Despite the variety of worldwide responses, none to date represent a break in the social relations of power and class definitive of the current era of finance-led neoliberalism. Continued dependence on world market flows of capital, reticence to reign in financial risk, and the strengthening of the financial apparatus - not to mention ongoing privatizations, massive lay-offs, the breaking of unions, severe cuts to public services, and the unwillingness to raise taxes on capital anywhere - instead represent the deepening social rule of finance-led neoliberal strategies of development. These strategies remain committed to the withdrawal of popular and political influence over the flows of capital within national borders and to protecting the power of finance to offload bad financial risks onto the state and society in times of crisis.

Put in more general terms, the tendencies of bank rescues are at base problems of social and class power, institutionalized in different ways according to the histories of specific societies. Without managing to account for the unequal social relations of power underlying aspects of universalization and differentiation, there is little chance policy-makers today will be able or willing to craft responses that break with this structural inequality. Stability may come with rescue, but it will come at the expense of workers, peasants, and popular classes and will be to the benefit of finance.

\section{ACKNOWLEDGEMENTS}

This work was carried out with the aid of a grant from the International Development Research Centre, Ottawa, Canada. Information on the Centre is available on the web at www.idrc.ca. This work was also made possible by the post doctoral support of the SSHRC of Canada. I appreciate the insightful comments of the referees and I would like to extend my thanks to Gregory Albo, Susanne Soederberg, Alfredo Saad-Filho, and the SOAS Research on Money and Finance collective for their critical input on earlier drafts. 


\section{NOTES}

1 'World Faces Deepening Crisis, IMF Chief Warns', IMF Survey Magazine, online, 21 January 2009. http://www.imf.org/external/pubs/ft/ survey/so/2009/new012109a.htm

2 'IMF-OECD-WB Seminar on the Response to the Crisis and Exit Strategies - Joint Statement', World Bank, online, 4 February 2009. http://web. worldbank.org / WBSITE / EXTERNAL / NEWS / 0,,contentMDK:22069548 menuPK:34463 pagePK:34370 piPK:34424 theSitePK:4607,00.html

3 IMF 2009a: 26; 'WB says Turkey has shock-proof financial system', Hurriyet online, 14 October 2008. http:/ / www.forbes.com/2008/10/08/wall-street-crisisent-fin-cx_kw_1008whartonlessons_2.html

4 'Learning from Nightmares', Forbes.com, 10 October 2008. Akçaoğlu, Emin (1998). Financial Innovation in Turkish Banking, Ankara: Capital Markets Board.

5 While the dynamics of bank rescue have received relatively little attention, the bank crises have been widely debated (see Akyüz and Boratav, 2003; Cizre and Yeldan, 2005; Öniş, 2006; Garrido, 2005; Guillén Romo, 2005; Stallings, 2006).

6 While beyond the scope of this article, some have narrowed the Mexican bank privatization debacle down to whether the prices paid were either high or too high (for example, Haber, 2005). Others have then reproduced the 'high versus too high' debate as an isolated fact (Avalos and Trillo, 2006: 17; Stallings, 2006: 187). Where circumstances are complex, too direct a line is drawn from the price paid to the 1995 banking crisis.

7 A high level SHCP director in the Banking and Saving Unit affirmed this official interpretation (Interview, 13 February 2008, Mexico City).

8 In 2002 figures, Korea's 1997 crisis cost more than 20 per cent of GDP, Malaysia's 1997 crisis 5 per cent, and Thailand's 1997 meltdown 43 per cent (OECD, 2002: 91). President Barack Obama's US stimulus package, valued at around 5.7 per cent of US GDP, seems almost frugal in relative terms.

9 Interview, 27 August 2007, Ankara.

10 Interview, Senior Manager, Halk Bank, 24 August 2007, Istanbul.

11 Interview, Bank and Saving Unit, 13 February 2008.

12 Griffith-Jones et al. (2004) discuss the problems of implementing Basel II for developing countries.

13 With the 2008-09 financial crisis bringing an end to Turkish economic growth, AKP President Recep Tayyip Erdoğan has questioned the principle of TCMB independence because it ties the hands of government action.

14 For debates on foreign control, see Avalos and Trillo (2006); Beck and Martinez Peria (2008); Guillén Romo (2005); and Girón (2005).

15 Many others also rightly point to how in emerging markets banks have turned to acquiring high-yield state debt securities, collecting high transaction commissions, driving up user fees for payment services, pushing high interest consumer debt, and minimizing loans to productive activities and SMEs to augment profitability (Gültekin-Karakaş, 2008; Guillén Romo, 2005; Toporowski, 2007; Stallings, 2006; Lapavitsas and Dos Santos, 2008).

16 Turkish profits are quite robust compared to OECD countries during the 1980s, for example, 1.38 per cent in Spain, 1.14 in Italy, and 0.5 in Germany (Akçaoğlu, 1998: 92).

17 Comparatively, the 2003 ROA for China's largely state-owned banking system was 0.1 per cent and Korea's largely mixed ownership system's ROA averaged 0.5 per cent (Stallings, 2006: 69-71). 
18 'Require la Banca Suficiente Capitalización: Banamex', El Financiero, 13 June 1990, p. 3.

19 www.londonsummit.gov.uk

20 'The Crisis and the Policy Response', Stamp Lecture at the London School of Economics, online, 13 January 2009.

\section{NOTES ON CONTRIBUTOR}

Thomas Marois is a lecturer of Development Studies at the School of Oriental and African Studies, London. He teaches on the political economy of finance, privatization, development, and neoliberalism. Thomas is currently working on a book-length manuscript addressing the problems of bank ownership, crisis, and finance-led neoliberal strategies of development in Mexico and Turkey.

\section{REFERENCES}

Akçaoğlu, Emin (1998) Financial Innovation in Turkish Banking, Ankara: Capital Markets Board.

Akyüz, Y. and Boratav, K. (2003) 'The Making of the Turkish Financial Crisis', World Development, 31(9): 1549-66.

Alavi, H. (1982) 'State and Class Under Peripheral Capitalism', in H. Alavi and T. Shanin (eds) Introduction to the Sociology of Developing Societies, New York: Monthly Review Press, pp. 209-307.

Albo, G. (2005) 'Contesting the "New Capitalism"', in David Coates (ed.) Varieties of Capitalism, Varieties of Approaches, New York: Palgrave MacMillan, pp. 63-82.

Allegret, J. P., Courbis, B. and Dulbecco, Ph. (2003) 'Financial Liberalization and Stability of the Financial System in Emerging Markets: The Institutional Dimension of Financial Crises', Review of International Political Economy, 10(1): 73-92.

Aubey, R. T. (1971) 'Regional Credit and the Mexican Financial System', Growth and Change, 2(4): 25-33.

Avalos, M. and Trillo, F. H. (2006) 'Competencia Bancaria en México', Santiago de Chile: Comisión Económica Para América Latina y el Caribe (CEPAL).

Balkan, E. and Yeldan, E. (2002) 'Peripheral Development under Financial Liberalization: The Turkish Experience', in Neşecan Balkan and Sungur Savran (eds) The Ravages of Neo-Liberalism, Huappauge, NY: Nova Science Publishers, pp. 13-54.

Banco de Mexico (1990-2006) Informe Annual, Mexico City: Banco de Mexico.

Barth, J. R., Caprio Jr., G. and Levine, R. (2006) Rethinking Bank Regulation: Till Angels Govern, New York: Cambridge University Press.

Bátiz-Lazo, B. and Del Angel, G. A. (2003) 'Competitive Collaboration and Market Contestability: Cases in Mexican and UK Banking, 1945-75', Accounting, Business, and Financial History, 13(3): 339-68.

BDDK (Bankacılık Düzenleme ve Denetleme Kurumu; Banking Regulation and Supervision Agency) (2001) Banking Sector Restructuring Program Action Plan, 25 September, Ankara, <www.bddk.org.tr> (accessed May 2009).

BDDK (2002) Banking Sector Reform: Progress Report, July, Ankara, $<$ www.bddk.org.tr $>$.

BDDK (2003) Banking Sector Restructuring Program Progress Report - (VII), October, Ankara, <www.bddk.org.tr $>$. 
Beck, T. and Martinez Peria, M. S. (2008) 'Foreign Bank Acquisitions and Outreach: Evidence from Mexico', Policy Research Working Paper 4467, World Bank.

Bello, W. (2006) 'The Capitalist Conjuncture: Over-accumulation, Financial Crises, and the Retreat from Globalisation', Third World Quarterly, 27(8): 1345-67.

Bennett, D. and Sharpe, K. (1980) 'The State as Banker and Entrepreneur: The Last-Resort Character of the Mexican State's Economic Intervention, 1917-76', Comparative Politics, 12(2): 165-89.

BYEGM (2005) Banking in Turkey, Office of the Prime Minister, Directorate General of Press and Information, <www.byegm.goc.tr/REFERENCES/ banking/htm $>$.

Cizre, Ü. and Yeldan, E. (2005) 'The Turkish Encounter with Neo-liberalism: Economics and Politics in the 2000/2001 Crises', Review of International Political Economy, 12(3): 387-408.

CNBV (Comisión Nacional Bancaria y de Valores) (2001 to 2008) Boletín Estadístico Banca Múltiple Diciembre, Mexico City: CNBV.

Cypher, J. M. (1989) 'The Debt Crisis as "Opportunity": Strategies to Revive U.S. Hegemony', Latin American Perspectives, 16(1): 52-78.

Del Ángel-Mobarak, G. A. (2005) 'La Banca Mexicana antes de 1982', in G.A. del Ángel-Mobarak, C. Bazdrech Parada and F. Suarez Parada (eds) Cuando el Estado se Hizo Banquero: Consequencias de la Nacionalizacion, Colecion Lecturas de El Trimestre Economico, 96, Mexico: Fondo de Cultura Economica, 43-56.

Demirgüç-Kunt, A. and Servén, L. (2009) 'Are All the Sacred Cows Dead? Implications of the Financial Crisis for Macro and Financial Policies', Policy Research Working Paper 4807, World Bank.

Duménil, G. and Lévy, D. (2001) 'Costs and Benefits of Neoliberalism. A Class Analysis', Review of International Political Economy, 8(4): 578-607.

Duménil, Gerard and Lévy, Dominique (2004) 'The Economics of US Imperialism at the Turn of the 21st Century', Review of International Political Economy, 11(4): $657-76$.

Ercan, F. (2002) 'The Contradictory Continuity of the Turkish Capital Accumulation Process: A Critical Perspective of the Internationalization of the Turkish Economy', in Neşecan Balkan and Sungur Savran (eds) The Ravages of NeoLiberalism, Huappauge, NY: Nova Science Publishers, 21-37.

Ercan, F. and Oguz, S. (2007) 'Rethinking Anti-Neoliberal Strategies through the Perspective of Value Theory: Insights from the Turkish Case', Science E Society, 71(2): 173-202.

Eres, B. (2005) 'Capital Accumulation and the Development of a Financial System: The Turkish Example', Review of Radical Political Economics, 37(3): 320-8.

FitzGerald, E. V. K. (1985) 'The Financial Constraint on Relative Autonomy: The State and Capital Accumulation in Mexico, 1940-82,' in C. Anglade and C. Fortin (eds) The State and Capital Accumulation in Latin America, Vol.1: Brazil, Chile, Mexico, London: MacMillan Press, pp. 211-235.

Furceri, D. and Mourougane, A. (2009) 'Financial Crises: Past Lessons and Policy Implications', Economics Department Working Papers, No. 668, Paris: OECD.

Garrido, C. (2005) Desarallo Económico y Procesos de Financiamento en México: Transformaciones Contemporáneas y Dilemas Actuales, Mexico City: Siglo XXI Editores/Universidad Autónoma Metropolitana.

Girón, A. G. (2005) 'El Sistema Financiero Mexicano. Regulación, Desregulación y Extranjerización', in G.A. del Ángel-Mobarak, C. Bazdrech Parada, and F. Suarez Parada (eds) Cuando el Estado se Hizo Banquero: Consequencias de la 
Nacionalizacion, Colecion Lecturas de El Trimestre Economico, 96, Mexico City: Fondo de Cultura Economica, 291-302.

Gómez-Galvarriato, A. and Recio, G. (2003) ‘Qué Ocurre cuando no Hay Banca? Los Bancos y la Revolución Mexicana', in G. A. Del Angel (ed.) La Banca en América Latina: Lecciones del Pasado. Retos al Futur, Mexico City: CIDE, pp. 51-55.

Grabel, I. (2000) 'The Political Economy of 'Policy Credibility': The New Classical Macroeconomics and the remaking of Emerging Economics', Cambridge Journal of Economics, 241: 1-19.

Greenfield, G. (2004) 'Bandung Redux: Imperialism and Anti-Globalization Nationalisms in Southeast Asia', in L. Panitch and C. Leys (eds) The Socialist Register 2005: The Empire Reloaded, London: The Merlin Press, pp. 166-196.

Griffith-Jones, S., Segoviano, M. A. and Spratt, S. (2004) `Basel II: Developing Countries and Portfolio Diversification', CEPAL Review, 83: 145-60.

Guillén Romo, H. (2005) México frente a la Mundialización Neoliberal, Mexico City, Ediciones Era.

Gültekin-Karakaş, D. (2008). Global Integration of Turkish Finance Capital, Saarbrücken, Germany: Verlag Dr. Mueller.

Haber, S. (2005) 'Mexico's Experiments with Bank Privatization and Liberalization, 1991-2003', Journal of Banking and Finance, 29(8-9): 2325-53.

Helleiner, E. (2006) 'Reinterpreting Bretton Woods: International Development and the Neglected Origins of Embedded Liberalism', Development and Change, 37(5): 943-67.

IMF (2006) Mexico: Financial System Stability Assessment Update, IMF Country Report No. 06/350, Washington, DC: IMF.

IMF (2007) Mexico: Financial Sector Assessment Program Update-Detailed Assessment of Compliance with the Basel Core Principles for Effective Banking Supervision and Transparency of Banking Supervision, IMF Country Report No. 07/172, Washington, DC: IMF.

IMF (2007a) Mexico: Financial Sector Assessment Program Update - Technical Note Financing of the Private Sector, IMF Country Report No. 07/170.

IMF (2009a) Mexico: 2008 Article IV Consultation. IMF Country Report No. 09/53, Washington, DC: IMF.

IMF (2009b) World Economic Outlook: Crisis and Recovery, Washington, DC: IMF.

Isık, thsan and Akçaoğlu, Emin (2006) 'An Empirical Analysis of Productivity Developments in "Traditional Banks": The Initial Post-Liberalization Experience', Central Bank Review, 1: 1-35.

Kiely, R. (2007) The New Political Economy of Development: Globalization, Imperialism, Hegemony, New York: Palgrave MacMillan.

La Porta, R., Lopez-de-Silanes, F. and Shleifer, A. (2002) 'Government Ownership of Banks', The Journal of Finance, 57(1): 265-301.

Lapavitsas, C. and Dos Santos, P. L. (2008) 'Globalization and Contemporary Banking: On the Impact of New Technology', Contributions to Political Economy, 27(1): 31-56.

Levy, Noemi Orlik (2003). 'Los Cambios Institucionales y su Efecto sobre la Estructura Financiera: Modificación de los Agregados Monetarios', ("Institutional Changes and their Effect over the Financial Structure: Modification of the Monetary Aggregates") Hacia una Política Monetaria y Financiera para el Cambio Estructural y el Crecimiento, ed. by E. Ortiz Cruz, Mexico City: UAM y Plaza y Valdes Editores.

Mannsberger, Jörg and McBride, J. Brad (2007) 'The Privatization of the Mexican Banking Sector in the 1990s: From Debacle to Disappointment', International Journal of Emerging Markets, 2(4): 320-34. 
Marois, T. (2005) 'From Economic Crisis to a 'State' of Crisis?: The Emergence of Neoliberalism in Costa Rica', Historical Materialism, 13(3): $101-34$.

Marois, T. (2008) 'The 1982 Mexican Bank Statization and Unintended Consequences for the Emergence of Neoliberalism', Canadian Journal of Political Science, 41(1): 143-67.

Marx, Karl (1990) [1976] Capital: A Critique of Political Economy, Vol. III, trans. by D. Fernbach, London: Penguin Classics.

McKinnon, R. I. (1973) Money and Capital in Economic Development, Washington, DC: The Brookings Institute.

Mishkin, F. S., (2009) 'Challenges for Inflation Targeting in Emerging Market Countries', Emerging Markets Finance and Trade, 44(6): 5-16.

Nachtwey, O. and ten Brink, T. (2008) 'Lost in Translation: The German WorldMarket Debate in the 1970s', Historical Materialism, 16(1): 37-70.

OECD (1998) Bank Profitability: Financial Statements of Banks 1998, Paris: OECD.

OECD (1999) OECD Economic Surveys: Turkey 1998-1999, Paris: OECD.

OECD (2001) OECD Economic Surveys: Turkey 2000-2001, Paris: OECD.

OECD (2002) OECD Economic Surveys: Mexico 2002, Paris: OECD.

OECD (2004) Bank Profitability: Financial Statements of Banks 1994-2003, Paris: OECD.

Ollman, B. (1993) Dialectical Investigations, New York: Routledge.

Öncü, A. and Gökçe, D. (1991) Macro-Politics of De-Regulation and Micro-Politics of Banks', M. Heper (ed.) Strong State and Economic Interest Groups: The Post1980s Turkish Experience, New York: Walter de Gruyter, pp. 99-117.

Öniş, Z. (2006) ‘Varieties and Crises of Neoliberal Globalisation: Argentina, Turkey and the IMF', Third World Quarterly, 27(2): 239-63.

Öniş, Z. (2009) ‘Beyond the 2001 Financial Crisis: The Political Economy of the New Phase of Neo-liberal Restructuring in Turkey', Review of International Political Economy, 16(3): 409-32.

Ortiz Martínez, G. (1993) 'The Modernization of the Mexican Financial System', in S. Faruqi (ed.) Financial Sector Reforms in Asian and Latin American Countries: Lessons of Comparative Experience, Washington, DC: The World Bank.

Özince, E. (2005) 'Turkish Banking System', Presentation by the Chair of the Turkish Banks Association of Turkey, Istanbul < http:/ / www.turkisheconomy. org.uk/banking.html\#>.

Panitch, L. and Gindin, S. (2003) 'Global Capitalism and American Empire', in L. Panitch and C. Leys (eds) The Socialist Register 2004: The New Imperial Challenge, London: The Merlin Press, pp. 1-42.

Panitch, L. and Gindin, S. (2004) 'Finance and American Empire', in L. Panitch and C. Leys (eds) The Socialist Register 2005: The Empire Reloaded, London: The Merlin Press, pp. 46-81.

Poulantzas, N. (2000) [1978] State, Power, Socialism, New York: Verso Classics.

Rodrik, D. (2008) 'Second-Best Institutions', NBER Working Paper, No. 14050, Cambridge, MA: National Bureau of Economic Research.

Rosen, Fred (1998) 'The \$55 Billion Bank-bailout Scandal (Mexico),' NACLA Report on the Americas, 32(3): 11-15.

Savran, S. (2002) 'The Legacy of the Twentieth Century', in N. Balkan and S. Savran (eds) The Politics of Permanent Crisis: Class, Ideology and State in Turkey, New York: Nova Science Publishers, Inc, pp. 1-20.

Shaw, E. S. (1973) Financial Deepening in Economic Development, Toronto: Oxford University Press.

SHCP (1998) Fobaproa: La Verdadera Historia, Mexico: SHCP. 
Sidaoui, José (2006) 'The Mexican Financial System: Reforms and Evolution 19952005', BIS Papers, 28: 277-93.

Soederberg, S. (2004) The Politics of the New International Financial Infrastructure: Reimposing Neoliberal Domination in the Global South, New York: Zed Books.

Stallings, B. with Studart, R. (2006) Finance for Development: Latin America in Comparative Perspective, Washington, DC: The Brookings Institution.

Sweezy, P. M. (1970) [1942] The Theory of Capitalist Development: Principles of Marxian Political Economy, New York: Monthly Review Press.

TBB (Türkiye Bankalar Birliği; Banks Association of Turkey) (1963-2009) Banks in Turkey, Istanbul, <http://www.tbb.org.tr $>$.

Tello, C. (1984) La Nacionalización de la Banca en México, Mexico City: Siglo Veintiuno Editores.

Toporowski, J. (2007) 'European Banks in the Developing World', SOAS Department of Economics Working Papers, 151: 1-15.

Tschoegl, A. E. (2004) “The World's Local Bank": HSBCs Expansion in the US, Canada, and Mexico', Latin American Business Review, 5(4): 45-68.

Vanberg, V. J. ( 2005). 'Market and State: The Perspective of Constitutional Political Economy', Journal of Institutional Economics, 1(1): 23-49.

Vidal, G. (2002) 'Bancos, Fortunas y Poder: Una Lectura de la Economía en el México del 2000', in Eugenia Correa and Alicia Girón (eds) Crisis y Futuro de la Banca en México, Mexico City: UNAM-Miguel Ángel Porrúa.

Weiser, T. (1990) 'Participacion Extranjera en el Nuevo Sistema Bancario, Demanda AMB; Exige Flexibilidad', El Financiero, 23 May, Mexico City, p. 5.

World Bank (2003) Turkey Country Economic Memorandum, Towards Macroeconomic Stability and Sustained Growth, Report No. 26301-TU, Washington, DC: World Bank.

World Bank (2005) The World Bank in Turkey, 1993-2004, Country Assistance Evaluation, Report No. 34783, Independent Evaluation Group, Washington, DC: World Bank.

Yalman, G. L. (2002) 'The Turkish State and Bourgeoisie in Historical Perspective: A Relativist Paradigm or a Panoply of Hegemonic Strategies?', in N. Balkan and S. Savran (eds) The Politics of Permanent Crisis: Class, Ideology and State in Turkey, New York: Nova Science Publishers, Inc, pp. 21-45.

Yilmaz, D. (2007) 'The Central Bank of the Republic of Turkey - The History, Recent Developments and the Future of Monetary Policy in Turkey', BIS Review, 57: $1-5$. 